\title{
A novel reconstruction of the left superior vena cava
}

\author{
Lauren C. Kane, MD, Winfield J. Wells, MD, and Vaughn A. Starnes, MD, Los Angeles, Calif
}

Superior vena cava (SVC) reconstruction can be technically challenging when converting from a single to a 2 -ventricle repair after bilateral bidirectional Glenn shunts. Reconnecting the right-sided SVC can usually be easily accomplished, but reconstruction of the left SVC may be problematic, particularly because rerouting across the anterior mediastinum may cause compression of a neoconduit. We describe a novel way to reconstruct the left SVC using an 8-mm ribbed polytetrafluoroethylene (Gore-Tex, WL Gore \& Associates, Flagstaff, Ariz) tube graft extension to redirect flow to the inferior vena cava (IVC).

\section{CLINICAL SUMMARY}

A 6-year-old girl weighing $16 \mathrm{~kg}$ presented with Down syndrome, double-outlet right ventricle with unrestricted pulmonary blood flow, mitral valve dysplasia with abnormal chordal attachments, mildly unbalanced atrioventricular (AV) canal defect with right dominance, and a bilateral SVC (left larger than right). The patient was initially palliated with pulmonary artery banding at 4 months of age. A severe viral respiratory infection developed at 1 year of age, and she required extracorporeal membrane oxygenation support. Because of persisting desaturation, a modified Blalock-Taussig shunt was added. At 22 months of age, she underwent bilateral bidirectional Glenn shunts and takedown of the Blalock-Taussig shunt because it was thought that the ventricular and AV valve morphology was not amenable to a 2-ventricle repair. At 6 years of age, she was referred to our service for a second opinion to explore the possibility of a 2-ventricle repair versus completion Fontan. After thorough evaluation, the AV valves were found to be acceptable for a Rastelli-type AV canal repair.

\section{SURGICAL PROCEDURE}

A Rastelli 2-patch correction for the AV canal was performed. The previously banded area of the main pulmonary artery was opened with a bovine pericardial augmentation

\footnotetext{
From the Children's Hospital of Los Angeles, The University of Southern California, Department of Cardiothoracic Surgery, Los Angeles, Calif.

Disclosures: Authors have nothing to disclose with regard to commercial support.

Received for publication Aug 28, 2011; revisions received Sept 29, 2011; accepted for publication Oct 21, 2011; available ahead of print Nov 21, 2011.

Address for reprints: Winfield J. Wells, MD, Children's Hospital of Los Angeles, The University of Southern California, Department of Cardiothoracic Surgery, 4650 Sunset Blvd MS\#66, Los Angeles, CA 90027 (E-mail: wwells@chla.usc.edu). J Thorac Cardiovasc Surg 2012;143:981-2 $0022-5223 / \$ 36.00$

Copyright (c) 2012 by The American Association for Thoracic Surgery doi:10.1016/j.jtcvs.2011.10.058
}

patch. The right Glenn was taken down, and the smaller right SVC was connected to the right atrium using a lateral wall trap door opening to reconstruct the posterior portion of the anastomosis and a bovine pericardial "hood" to complete the connection. Overall, the right atrium was small and scarred from the previous surgeries with no right atrial appendage. The larger left SVC needed to be reconnected to the systemic venous drainage because there was elevated pulmonary artery pressure after septation and opening of the right ventricular outflow tract banded area. The option of any tube graft extension of the left SVC to the right atrium or right SVC would have required routing a conduit over or under the great vessels with likely compression by the sternum if passing anterior and compression in a narrow aortopulmonary window if passing under the aorta.

By using a novel technique, an 8-mm ringed polytetrafluoroethylene (Gore-Tex) tube graft was used to connect the left SVC to the IVC at its junction with the right atrium. A side-biting clamp was used to control the IVC with an opening for the anastomosis made medially. The conduit

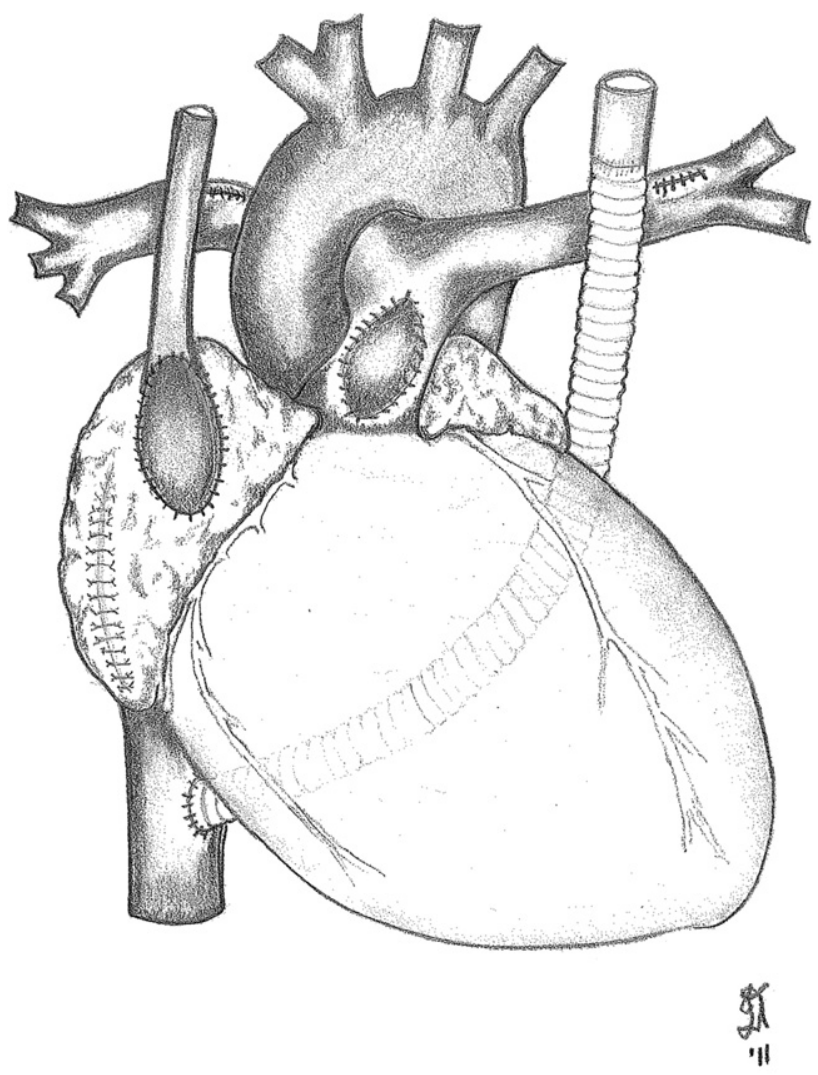

FIGURE 1. Reconstruction of the left SVC. 
passed behind the heart to reach the IVC (Figure 1). A ringed polytetrafluoroethylene (Gore-Tex) conduit was used to mitigate against compression by the heart. Warfarin was given for 6 months postoperatively with a goal international normalized ratio of 1.5 to 2.0 , followed by aspirin therapy alone. One year after discharge, an echocardiogram showed unobstructed conduit flow.

\section{DISCUSSION}

Takedown of a Glenn shunt has been reported, but it is uncommon. In particular, there is a paucity of information on take-down and reconstruction of a left-sided Glenn in patients with atrial situs solitus. ${ }^{1,2}$ Coloni and colleagues ${ }^{3}$ describe using ringed and non-ringed PTFE grafts, as well as a conduit made from autologous or bovine pericardium to reconstruct the SVC and left brachiocephalic veins. Mahesh and Ratnatunga ${ }^{4}$ reported reconstruction of the SVC with aortic and pulmonary homograft in patients with SVC occlusion due to benign or malignant pathology.

\section{CONCLUSIONS}

The technique we have described is most relevant in the pediatric population, in whom chest wall compression of an anteriorly located conduit used for reconstruction of the left SVC has the greatest potential to be problematic. The major disadvantage to the technique we describe is the potential for thrombosis in the relatively long, small-caliber PTFE (Gore-Tex) graft. As has been our practice with patients undergoing Fontan by the extracardiac conduit technique, we plan to anticoagulate with warfarin (international normalized ratio, $\sim 2.0$ ) for approximately 6 months and then transition to aspirin.

The authors thank Dr Irving Tessler for providing the medical illustration.

\section{References}

1. Pacifico AD, Kirklin JW. Takedown of cava-pulmonary artery anastomosis (Glenn) during repair of congenital cardiac malformations. $J$ Thorac Cardiovasc Surg. 1975;70:272-7.

2. Rohmer J, Quaegebeur JM, Brom GA. Takedown and reconstruction of cavopulmonary anastomosis. Ann Thorac Surg. 1977;23:129-34.

3. Venuta F, Rendina EA, Coloni GF. Surgery of the superior vena cava: resection and reconstruction. Thoracic Techniques. 19 Oct 2009. Available at: http://www.ctsnet. org/sections/clinicalresources/thoracic/expert_tech-6.html. Accessed March 23, 2011 .

4. Mahesh B, Ratnatunga C. Superior vena cava reconstruction with homograft conduit under circulatory arrest. Asian Cardiovasc Thorac Ann. 2007;15: $345-7$.

\title{
Venovenous extracorporeal membrane oxygenation using a single cannula in patients with pulmonary hypertension and atrial septal defects
}

\author{
Jeffrey Javidfar, MD, ${ }^{a}$ Daniel Brodie, MD, ${ }^{\mathrm{b}}$ Joshua Sonett, MD, ${ }^{\mathrm{a}}$ and Matthew Bacchetta, MD, ${ }^{\mathrm{a}}$ New York, \\ NY
}

Adults with unrepaired congenital septal defects are at risk of developing Eisenmenger's syndrome, characterized by pulmonary hypertension and right ventricular failure. If such patients fail medical therapy and acute on chronic cardiopulmonary failure develops, they can be supported with venoarterial extracorporeal membrane oxygenation $\left(\right.$ ECMO) until they recover or receive a transplant. ${ }^{1}$

\footnotetext{
From the Divisions of Cardiothoracic Surgery a and Pulmonary, Allergy, and Critical Care Medicine, ${ }^{\mathrm{b}}$ Columbia University Medical Center, New York, NY.

Disclosures: Authors have nothing to disclose with regard to commercial support.

Received for publication May 2, 2011; revisions received Sept 18, 2011; accepted for publication Oct 21, 2011; available ahead of print Dec 5, 2011.

Address for reprints: Jeffrey Javidfar, MD, Columbia University Medical Center, Herbert Irving Pavilion, 161 Fort Washington Ave, Suite 301, New York, NY 10032 (E-mail: jj2316@ columbia.edu).

J Thorac Cardiovasc Surg 2012;143:982-4

$0022-5223 / \$ 36.00$

Copyright (C) 2012 by The American Association for Thoracic Surgery

doi:10.1016/j.jtcvs.2011.10.061
}

Standard approaches to venoarterial ECMO require both venous and arterial cannulation. In addition to requiring a second cannula, without a concomitant ancillary antegrade catheter, peripheral arterial cannulation is associated with the risk of limb ischemia.

The Avalon Elite Bicaval Dual Lumen catheter (Avalon Laboratories, LLC, Rancho Domingez, Calif) allows for adult venovenous ECMO through a single cannulation site. $^{2}$ The catheter has a right atrial infusion port that can take advantage of the congenital atrial septal defect (ASD) (Figure 1) and shunt oxygenated blood into the left side of the heart while the other lumen drains the venae cavae. ${ }^{2}$ Camboni and colleagues ${ }^{3}$ confirmed right to left atrial shunting of oxygenated blood when using this cannula for ECMO in sheep. We present the novel use of this catheter to provide venovenous ECMO with a physiologic shunt and right ventricular decompression without an arterial cannula. 